\title{
中国におけるメッツォ最新技術の導入についで*
}

\author{
メッツォSHI 株式会社 山 崎 秀 彦
}

\section{Introduction of Advanced Metso Paper Technology into China}

\section{Hidehiko Yamazaki}

Metso-SHI Co., Ltd.

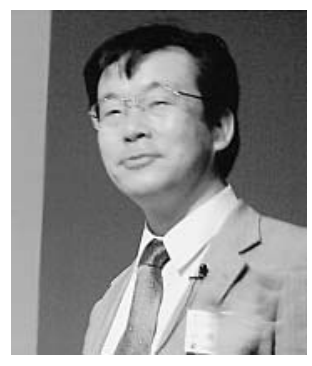

Recently Chinese paper industries have been showing rapid development, in which Japanese papermakers have a serious interest. While the paper and board demands in advanced countries including Japan seem to have reached ceiling level, the paper and board demand in China still shows rapid increase. Total production of paper industries in China in 2002 was 37.8 million tons, which showed 8. $4 \%$ increase compared to that a year before. Although new machines were installed in China year by year, the domestic demand of paper and board is expected to keep increasing due to further economic growth and large population of potential consumers.

Metso Paper has a regional company in Beijing, Service Technology Center in Wuxi and ValmetXian as a joint-venture company in Xian, which enhance Metso Paper's business, production and customer service in China. Recent noteworthy point is that the world first OptiConcept machine was installed and started up in Nanping, China earlier than in European countries, and achieved satisfactory results.

In this paper, the future prospect in Chinese paper industries and representative paper machine technologies delivered by Metso Paper are described.

分類: $\mathrm{M}_{1}$ 抄紙・抄紙機一般, $Z_{2}$ 紙パルプ産業一般

\section{1.はじめに}

近年，中国での製紙産業の急速な発展はわが国の製 紙業界でも大きな関心が寄せられている。日本を始め とする先進国での紙・板紙の需要がほぼ横這いである のに対して, 中国での紙・板紙の需要は急速な成長を 示している。2002 年の中国の製紙産業の総生産は 3,780 万トンであり, 前年に比べて $8.4 \%$ の成長を示 した。抄紙機の新設が続いているものの, 経済発展と

*第 9 回製紙技術セミナー講演
膨大な人口による潜在的消費者の数から大方の予測で は将来にわたって中国国内での需要が伸び続けるもの と考えられている。

メッツォペーパーは, 中国では北京に支社, 西安に 合弁会社である Valmet-Xian 社, 無錫（ウーシー）に サービス技術センターを有し, 中国でのビジネス，製 造, サービスに努めている。これは, とりもなおさず 近年，中国での製紙会社からの受注の増，それに伴う マシン稼動, そしてサービスを充足するためのもので ある。近年の特筆すべき点は, メッツォの技術の粋を 集めた最新式の OptiConcept 抄紙機が中国に設置, 
稼動し，さらに成果を上げていることである。1998 年, メッツォペーパー (旧バルメット社) は 21 世紀 に向けての革新的な抄紙機コンセプトである OptiConceptを発表した。これは抄紙機のすべてのセクシ ヨンを含んで抒り, 抄速 $2,000 \mathrm{~m} / \mathrm{min}$ の達成を目標 として開発されたものである。現在では, 既に何台か の OptiConcept マシンが世界で稼動しているが, そ の第 1 号機を中国の南平（ナンピン）造紙廠ナンピン 工場に新聞用紙用マシン PM 5 として納入し,1999 年 12 月にスタートアップさせている。その後, 同型の 抄紙機をチチハル製紙にも設置している。その後も最 新型マシンの導入は続いている。メッツォペーパーに とって, 現在, 将来ともに極めて重要な市場である。

本稿では, 中国の今後の展望とこれまでメッツォペ ーパーが中国に導入した製紙機械技術の代表的なもの について紹介する。

\section{2. 中国の製紙産業の展望}

世界の各地域の紙パ産業の長期的に見た需要を比較 してみると, 北米では市場は成熟しているため成長率 は年 $1 \%$ 強程度, ヨーロッパは成熟途中（西ヨーロ ッパは成熟, 東ヨーロッパは成熟途上）の市場であり 成長率は年 2-3\%, 南米では市場は拡大しつつあり成 長率は年 3-4\%，そしてアジア太平洋地域ではさらに 急成長が考えられ成長率は年 4-5\% と推定される。全 世界的には成長率は年 $2-3 \%$ と見られる。なかでも中 国の需要の伸びは大きく, 1990 年から 2000 年は年間 $9.2 \%$ といった急成長ぶりである。2000 年から 2010 年も年間 $6.2 \%$ の伸びが見積もられる。成長はなお続 き 2010 年から 2020 年においても年 $4.1 \%$ の成長が見 積もられる。

中国の国立紙パルプ研究所の Zhenlei Cao 氏によれ ば，中国で一人当たりの GDP が 1,000 元増せば，一

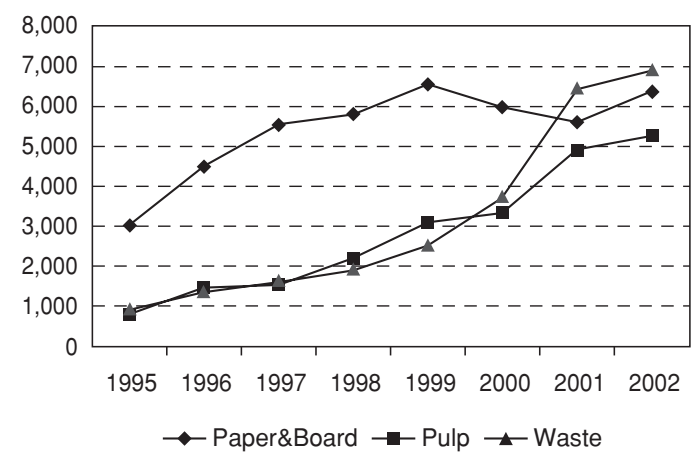

図 1 1995-2002 年の中国の紙・板紙, パルプおよび 古紙の輸入 (Caoによる)
人当たりの紙・板紙の消費量は $3 \mathrm{~kg}$ 増加する。それ でもし中国経済が年率 $7 \%$ 成長し, 人口増加率とし て過去 12 年間の值 $0.91 \%$ を用いれば，一人当たりの GDP は 2010 年までに 13,890 元となり，一人当たり の紙・板紙消費量は $50 \mathrm{~kg}$ となる。ゆえに中国での紙 ・板紙消費は 2005 年までに 50, 180, 000 トンにな り，2010 年までに $68,500,000$ トンになることが推測 される。

また, 別の予測では, 紙・板紙の輸出国, 輸入国の 関係は長期的に見てもほぼ維持され，スカンジナビア 諸国, 北米は今後も主たる輸出国であり, 西ヨーロッ パ, 中国, 中南米, アフリカは輸入国であり続けると みられている。また, 図 1 は, 1995-2002 年の紙・板 紙，パルプおよび古紙の輸入を示している。紙・板紙 の輸入は国内の生産能力の増加につれて変化したもの の, パルプと古紙の輸入は 1995 年以来着実に増加し ている。今後の紙・板紙のマシンの新たな設置が続い ても, なお需要を満たしきれず多量の紙・板紙の輸入 が続き，また製紙原料であるパルプおよび古紙の輸入 も当分は増加していくものと考えられる。

Jaako Poyry の統計によれば，1999 年現在で全世界 の抄紙機台数は 8,671 台であり, 中国には 1610 台の マシンがあり, 他のどの地域よりも多くの抄紙機を保 有している。しかしこれらの多くは旧式のマシンで抄 速，マシン幅ともに小さなものである。こうしたなか, 一方では最新式抄紙機の導入が盛んに行われているの が中国の実情である。

\section{3. 中国におけるメッツォペーパーの最新抄紙機}

メッツォペーパーが中国に導入した最新式抄紙機に ついて代表的なものを次に紹介する。

\section{1 南平（ナンピン） PM 5}

\subsection{1 新抄紙機導入の経緯}

南平造紙廠の南平 (ナンピン) 工場はもともと 1958 年に 2 台の抄紙機を有する工場として建設された。 1982 年以降は, PM 3 と PM 4 が稼動していたが, 製 品品質と効率が劣っており, 製品品質は顧客の要求を 満たすことができなかった。PM 1 と PM 2 は 1998 年 に稼動を停止した。こうして，同社は，新しい新聞用 紙製造ラインの準備を始め, $100 \%$ 古紙を用いた新聞 用紙の製造を目標として, 新製造ラインが福建省のナ ンピンに建設されることとなった。当地は, 沿岸では なく輸入古紙の使用には不便があるももの沿岸のグリ ーンフィールドでの工場建設に比べると, 発電所, ス チームシステム, 用水システムといったインフラが既 に存在していた点が有利であった。 

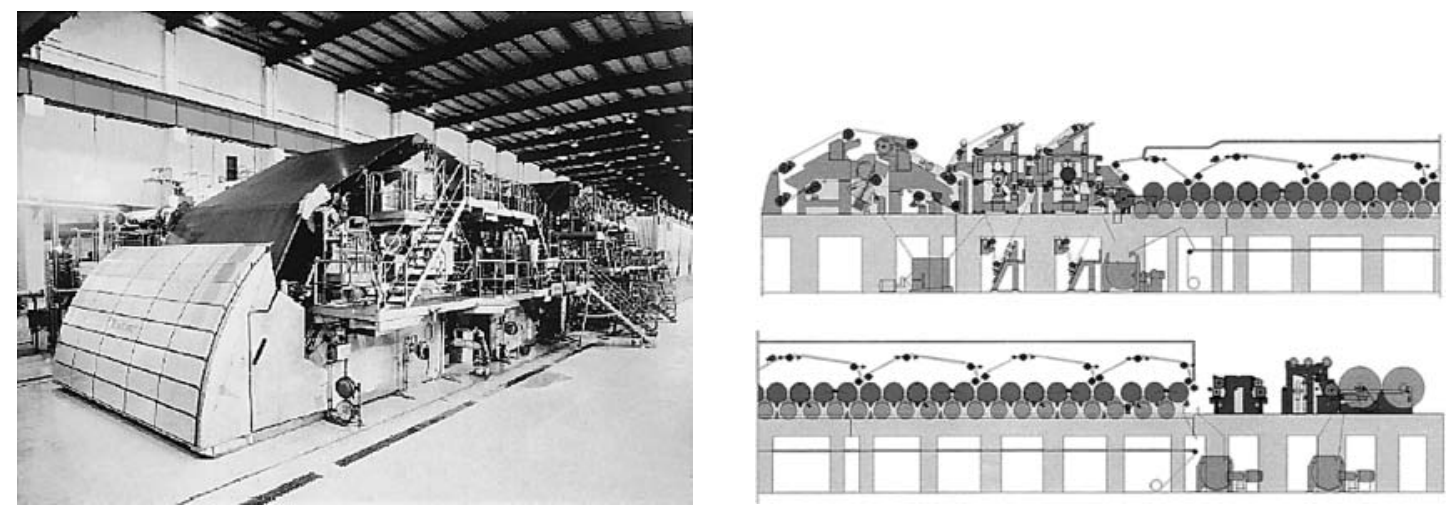

図 2 ナンピン PM 5 の OptiConcept 抄紙機

新しい新聞用紙の製造ラインには，品質要求を満た し信頼性のある抄紙機を導入することが求められ，工 場の代表者は各抄紙機メーカーと代表的な製紙工場を 訪問し，機種の検討を行った。その結果，バルメット の OptiConcept が高度の信頼性を有した新聞用紙製 造法であると評価され，導入が決定された。

\subsubsection{OptiConcept 抄紙機}

ナンピン PM 5 にはバルメットの最新技術である OptiConcept 抄紙機のラインが世界で初めて導入さ れ，1999 年 12 月に生産を開始した（図 2)。設計抄速 は $1,800 \mathrm{~m} /$ 分であり, ワイヤ幅は $6,100 \mathrm{~mm}$ である。 紙料調成システム（紙料の配合，ブローク処理，精選， 濃縮, 繊維回収など), ウェットエンド薬品ハンドリ ングシステム, OptiFloヘッドボックス, OptiFormer, OptiPress, エアシステム (SymRun ドライヤ, フー ド, ランナビリティシステムなど), OptiSoft ソフト カレンダー, OptiReel Plus, WinDrum M ワインダー およびDamaticＸdi オートメーションパッケージ， ロールハンドリングシステムなどが含まれる。

これらのうちいくつかの特徵を以下に記す。

(1) OptiFloヘッドボックス

ディルーションコントロール式ヘッドボックスであ り, オンライン調節により広範囲の流量範囲とその他 のプロセス変数についてクローズドループコントロー ルを可能にする。エッジフローコントロールは瀻維配 向に起因する紙の性質を最適化するためのプログラム アシストによる方法を提供する。ナンピンの抄速，流 量範囲, 繊維組成および新聞用紙の要求品質を考慮し てヘッドボックスは作製された。OptiFloにはIQへ ッドボックスによる希釈プロファイル, エッジフロー およびタービュランスコントロールの機能を有してい る。これにより, 抄替えやスタートアップなどの変更 の時間を短縮でき，全体の効率の向上が図れる。

\section{(2) OptiFormer}

OptiFormer（図 3）はバルメットがギャップフォ ーマーとしてすでに確立させたロールアンドブレード フォーマー技術を発展させたものであり, フォーミン グゾーンをモジュール化した構造をとっている。両面 からの均等脱水が実現され, 表裏差のない紙が得られ る。良好な走行性とシャットダウン時間の最短化によ り高速運転に必要な高い効率が達成できる。

新聞用紙はカラーインキの吸収のために十分な多孔 性が必要である。他の性質として, 良好な地合, 高い 表面強度による低いリンティング性および, および高 い嵪と不透明度である。他の中質紙種では, 良好な走 行性は高い MD 引張強さを必要とする。ナンピンの マシンでは, OptiFormer はローダブルブレードモジ ユールを有しており, 強い脱水パルスを与えることに より優れた地合を形成する。

\section{(3) OptiPress}

従来のプレスはシュープレスの導入により, 飛躍的 に生産性を向上させた。さらに抄速を上げるにはセン ターロールからのシートリリース性が最も重要なファ クターとなる。バルメットは $2,000 \mathrm{~m} /$ 分以上の抄速 を許容するクローズドドローのコンセプトをすでに発 表している。これはセンターロールを有しないストレ ートスルータイプのプレスであり, かつオープンドロ

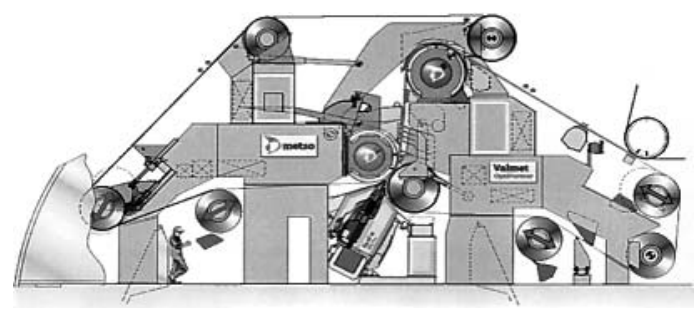

図 3 OptiFormer 


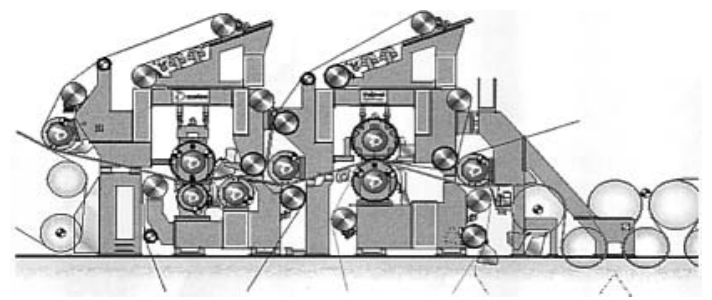

図 4 OptiPress

一も存在しないため走行性が良好である。この OptiPress には第 1 ニップにロールまたはシュープレス, 第 2 ニップにシュープレスを有するニップ配置をとり， フェルティングについては, 第 1 ニップ, 第 2 ニップ ともにダブルフェルトを用いるコンセプトと第 2 ニッ プのボトム位置にトランスファーベルトを用いるコン セプトがある。トランスファーベルトの表面は疎水性 と親水性の領域があるパターンで構成されており，こ れらの領域が最適なウェブガイドのための独特な圧力 反応性を与える。ベルトはほとんど水を吸収しないの で，ウェブのリウェットは生じない。トランスファー ベルトはウェブのピックアップ性， ウェブサポートお よびリリース性を向上させる機能を有している。これ らの機能によりクローズド化したシート移送を完全な ものにしている。ウェブのリウェットは抑制され，ド ライネスが向上する。ナンピンの OptiPress（図 4) は トランスファーベルトを有するデザインを採用してい る。PressRun ブローボックスとトランスファーベル トの組み合わせが OptiPress とドライヤセクションと の間のオープンドローを閉じ，ウェブに安定性を与え る。

(4) SymRun ドライヤ

ドライヤはシングルデッキの SymRun ドライヤであ る。また, 安定したウェブの走行のため, SymRun HS ブローボックスが据えられている。

(5) OptiSoft カレンダー

PM 5 のカレンダーは, 雨面のカレンダリングのため の 2 ニップソフトカレンダーであり, 速度は最高 $1,800 \mathrm{~m} /$ 分である。信頼性が高いこととロール交換 の容易さにより, OptiSoft は高い効率をもたらしてい る。また，カールコントロールのため, ControSteam モイスチャリングシステムを装備している。 ProfiSteam スチームボックスには IQMoisture センサ ーのプロファイルに基づきコントロールされる。CD キャリパーコントロールには IQ キャリパーセンサー から測定プロファイルを得て行われる。そして MD コントロールは PaperIQ システムで行われる。

\section{(6) OptiReel Plus}

OptiReel Plus 3 つのリーリングパラメータ，す なわち線圧, トルクおよびウェブ張力の制御と最適化 を図りつつウェブを巻き取る。これにより大径の親巻 きロールを作りライン全体の効率を向上させることが できる。

\section{(7) WinDrum M ワインダー}

ナンピンは 2 台の WinDrum M ワインダーを有し ている。それらは同一のもので, トリム幅が $5,509 \mathrm{~mm}$ で最大ドライブスピードが $2,300 \mathrm{~m} /$ 分である。親巻 きリールは普通 9 ないし 10 セット作り, 各カスタマ ーロールは直径約 $100 \mathrm{~cm}$ で, 幅は $78 \mathrm{~cm}$ から $156 \mathrm{~cm}$ の範囲である。平均運転速度は $1,800 \mathrm{~m} /$ 分とのこと である。

\section{1 .3 その後のナンピン PM 5}

以下に, ナンピンの顧問である Lin Yiting 氏の報告 から抜粋して紹介する。

スタートアップの 1 年後, このマシンは設計速度で ある $1,600 \mathrm{~m} /$ 分に到達した。初年度の新聞用紙の製 造量は 150,000 トンであり, 設計能力の $83.3 \%$ であ る。 1 年半の後, このマシンは 3 時間であるが 1,738 $\mathrm{m} /$ 分の速度を記録した。しかし, パルピングの能力 がマシンに供給するのに十分でなかったため, 速度を $1,600 \mathrm{~m} /$ 分に戻した。2001 年 9 月には, 坪量 $45 \mathrm{~g} / \mathrm{m}^{2}$ の新聞用紙を製造し始めた。2001年における総生産 量は 187, 606 トンであり，設計能力の $104.3 \%$ である。

マシンのスタートアップ以来, 逐次最適化が図られ, 効率は上昇し, 原単位はしだいに減少した。水消費量 は $10 \mathrm{~m}^{3} / \mathrm{t}$, 蒸気消費量は $1.4 \mathrm{t} / \mathrm{t}$ であり, いずれも中 国では最良である。2001 年の平均生産量は $941.5 \mathrm{~kg} /$ $\mathrm{cm} / \mathrm{d}$ であり, 速度は $1516 \mathrm{~m} /$ 分, 効率は $88.4 \%$, 全 世界の新聞マシンのなかで 10 位にランクした (Metso \&CPPAの統計による)。

さらに重要なのは, PM 5 のスタートアップの成功 によって中国の紙パルプ産業における考え方を変えさ せたという事実である。約 10 年前, 多くの理由から， いくつかの製紙工場は多量の中古マシンを輸入してい た。しかし, 結果としてみると, 最新鋭の設備は高い 生産性, 良い品質, 高い効率, 低い製造コストを実現 させ，市場競争力を増すのみならず，長期的な観点か らして理にかなった投資を必要とすることになる。

なお，同工場はPM 5 の稼動に合わせていくつかの 改善を図っている。その1つはウエットエンド化学に 着目したことである。従来は, 抄紙機（PM 1-4）の 抄速も遅く, 化学助剤にはそれほど敏感でなく, 薬品 の投与について注意を払っていなかった。それで，ス 
ライムの問題，フェルトの污れ等の問題があり，清掃 のために 4 日ごとに抄紙機を停止させていたという。

PM 5 の稼動に際しては, 使用する紙料に基づいた化 学薬品の最適化の理解が不可欠であり, そのための教 育が行われた。最適化の結果, フェルトの洗浄周期は 7 日から 14 日に延長でき, 紙の表面強度も大幅に改 善された。

もう 1 つは, パルピングシステムの最適化である。 同工場は, 従来, 5 つのパルピングライン, 即ち BKP, GP 1, GP 2, TMP および DIP 1 を持っていた。BKP, GP 1 と GP 2 は 20-30 年前に作られたため, システム は極めて古く, 貯蔵夕ワーの濃度はふつう 2.8-3.0\% と非常に低い。この低濃度は高速マシンである PM 5 には不適当であり, そのためタワーのアジテーターを 改造し, 紙料の貯蔵タワーの濃度と PM 5 へのポンプ 流送濃度を増加させるようにより大きなポンプを用い ることにし, 問題は解決した。また, 紙料に用いる GP と TMP は樹脂分が多く, 深刻なピッチトラブルを引 起す。対策をいろいろ検討し, 結果として適切な酵素 を適量使用することで，ピッチトラブルは解消した。

この他, 適切なファブリックの選択, シュープレス のメンテナンスのためのオペレーター教育などの徹底 が挙げられる。今では, シュープレスのベルトは $3-4$ ヶ月, トランスベルトは 5-6 ケ月（7 ケ月の記録あり） の間，連続して使用できるようになった。また，抄紙 機全般のメンテナンスの仕方も以前とは大きく変わる ことになった。以前は, 問題あるごとに対処するとい った考え方での修理保守が中心であったが, 現在, こ れは予防保守に置き換えた。抄紙機を一定した高い効 率で運転し続け, 紙品質を強化することは非常に重要 であるからである。さらに同工場は, サプライヤーと
の良好関係の維持を重視しており，さまざまな問題点 の解決に当たっている。

\section{2 チチハル PM 8}

上述したナンピン PM 5 と同型の OptiConcept 新聞 用紙用抄紙機が，ブラックドラゴン社チチハル製紙チ チハル PM 8 に設置され, 2001 年 4 月に稼動した。設 計速度 $1,800 \mathrm{~m} /$ 分, ワインダーでの最大トリム幅は $5,509 \mathrm{~mm}$ である。生産能力は年 18 万トンである。 原料は, APMP (Alkaline peroxide mechanical pulp), SGW および輸入化学パルプを含む原料を用いている。 当抄紙機は 24 時間速度として $1,305 \mathrm{~m} /$ 分を記録して いる。

\section{3 ユエヤン (岳陽) PM 8}

岳陽紙業集団は, 湖南省の岳陽工場で 2003 年 7 月 にOptiConcept 製紙ラインであるユエヤン PM 8（図 5）をスタートアップした。当抄紙機は新聞用紙と LWC の併抄マシン, いわゆるスウィングマシンであ り，必要に応じてどちらの紙種も抄紙することができ る。設計抄速は $1,600 \mathrm{~m} /$ 分, トリム幅 $6.3 \mathrm{~m}$ であり, 主な坪量は $60 \mathrm{~g} / \mathrm{m}^{2}$ であり, 紙料は主として国内産ポ プラパルプを用いる。

この PM 8 は高品質の新聞を日産 580 トンの生産, または LWC 紙を日産 715 トンを生産することができ る。

本年 7 月 1 日のスタートアップ時に, 同マシンはリ ールで $1,280 \mathrm{~m} /$ 分の速度を達成した。このオンライ ン OptiConcept 抄紙機は OptiFloヘッドボックス, OptiFormer, OptiPress, SymRun ドライヤセクショ ン, OptiHard マシンカレンダー, OptiSizer フィルム 塗工システム, OptiLoad カレンダーおよび OptiReel Plusからなっている。このほか, WinBelt M ワイン
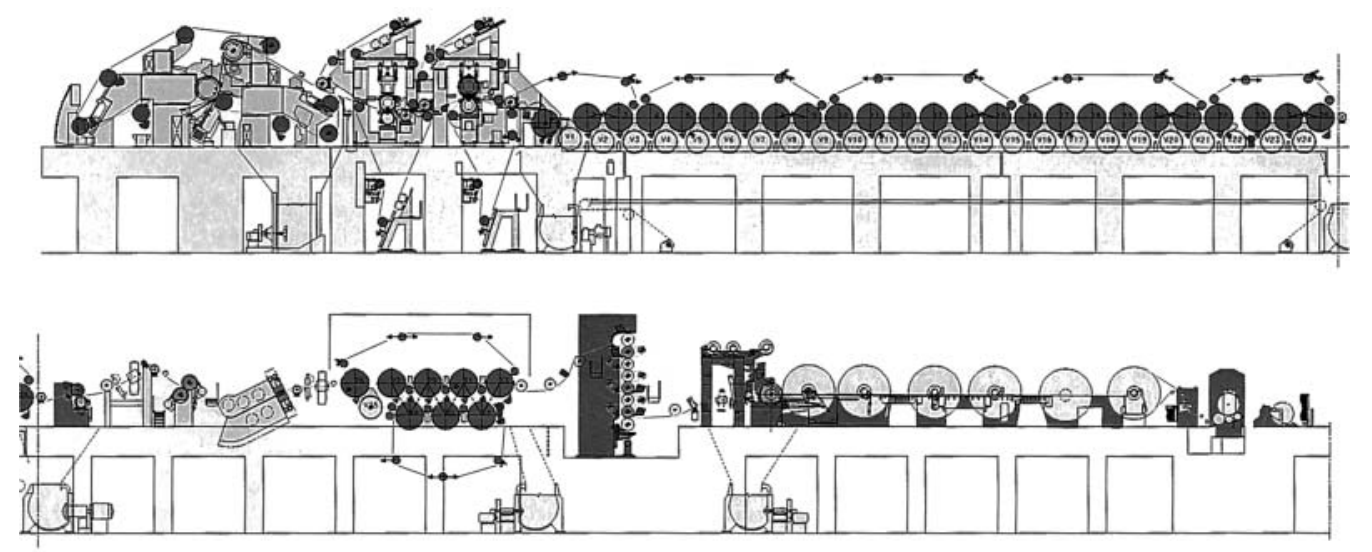

図 5 ユエヤン PM 8 


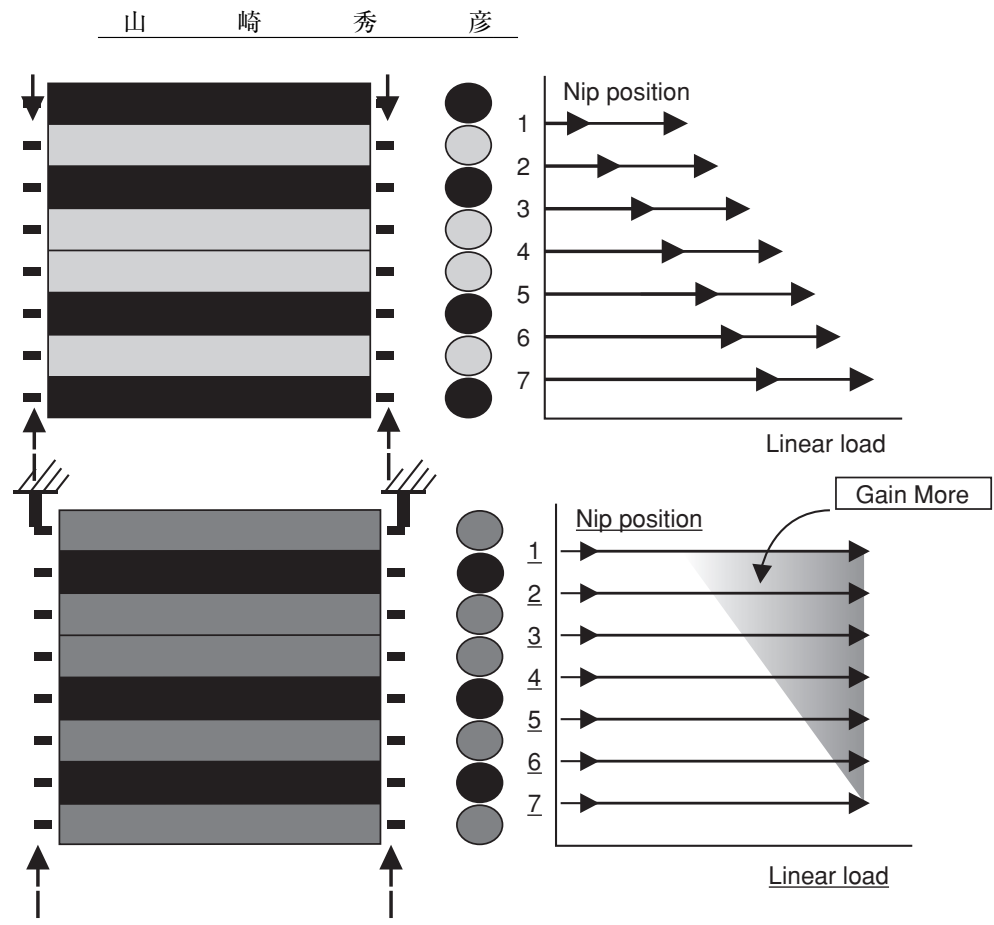

Conventional

supercalender

Gravity of rolls effect

to linear load

Load increase through

the stack

OptiLoad

Gravity of rolls is

eliminated

$100 \%$ Relief

-> More Calendering

capacity

図 6 OptiLoad の幅広い操作ウインドー

ダーとメッツォオートメーションのコントロールシス テムが含まれる。

現在，同機は新聞用紙を製造しており，一時的には 既に設計抄速を上回っている。また，LWCについて はこの秋, LWC に必要な原料調製を行った段階でテ ストを行うことになっている。鋈工，マルチニップカ レンダー処理がオンラインで行われる LWC の抄紙の 折は OptiSizer による塗工, オンラインの OptiLoad による表面仕上げが行われる。

OptiLoad はスーパーカレンダーに代わる高機能マ ルチニップカレンダーであり, スーパーカレンダーと 違い, 独特のロール配置を有し, より高い温度を使用 し，かつすべてのニップについて均等ニップ線圧の達 成による効果的なカレンダー処理が行えるのが特徵で ある（図 6)。低ニップ線圧から高ニップ線圧まで操 作ウィンドーを幅広くとることができる。

このマシンは前述したようにスウィングタイプであ るため，いくつかの異なった紙料成分が用いられる。 例えば，短繊維および長瀻維のクラフトパルプ, DIP, CTMP およびその他のメカニカルパルプである。

この紙料調製は新しい脱インキラインと OptiFeed ウェットエンドシステムによって行われる。

脱インキラインには新聞古紙, 雑誌古紙㧍よびオフ イス古紙を原料に用いる。ラインの能力日産 300 トン である。この脱インキラインは, OptiSlush ドラムパ
ルピング, OptiScreenの粗選, 前精選および精選, OptiBright の主および脱インキ後のフローテーショ ン, クリーニング, 濃縮, OptiFiner 分散, OptiBright 高濃度パーオキサイドと還元漂白, OptiThick ギャッ プウオッシングおよび OptiDaf 水浄化を含む主要な サブプロセスを含んでいる。

OptiFeed ウェットエンドシステムはパルプの貯蔵 タワーから抄紙機のヘッドボックスまでの主要なサブ プロセス，すなわち紙料ライン，ブロークシステム， 紙料混合, アプローチシステム, ウェットエンド薬品 の取り扱い拉よび白水取り扱いを含んでいる。

また, クラフトラインの特徴は OptiSlush ベールパ ルパー, OptiScreen 粗選および OptiFiner リファイ ニングと続いて設置された Kajaani KSF フリーネス トランスミッターである。紙料成分の配分とレシピは 各ラインで正確にコントロールされ, 流量測定によっ て迅速な配合変更が可能となる。メッツォオートメー ションのIQStock は紙料ラインでの流量情報と濃度 コントロールを実行する。

\section{4 ゴールドイーストペーパー（金東紙業）の OptiCoater ライン}

\subsection{1 塗工紙製造の環境条件}

中国のゴールドイーストペーパー社（江蘇省）は 29 ある APP 工場のうちの1つである。これは, 中国 の最大の製紙工場の 1 つであり, 上級塗工紙を年間 


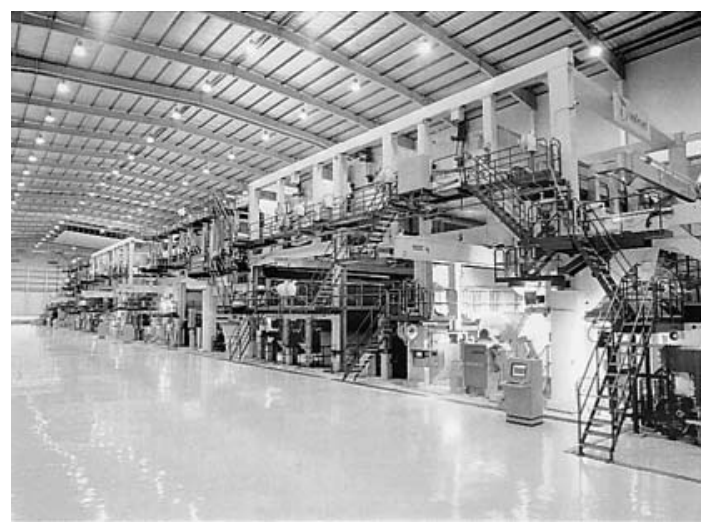

図 7 ダガンの OptiCoater（OMC 2)

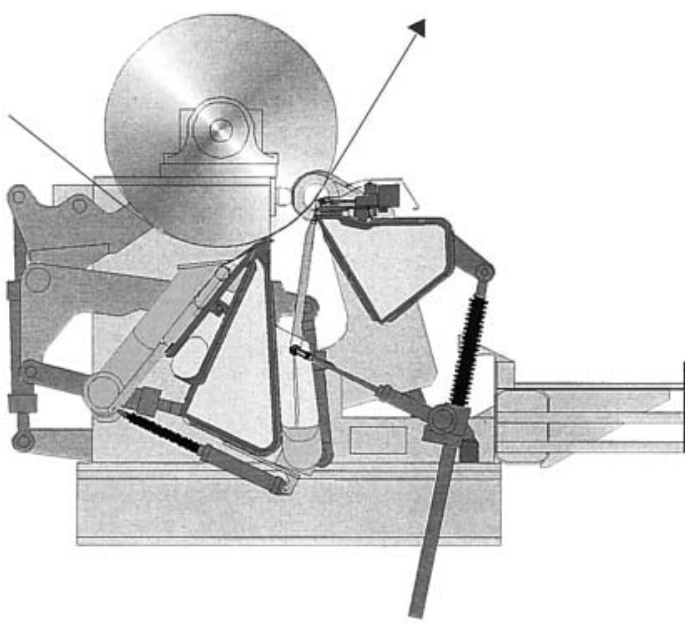

図 8 OptiCoat Jet

100 万トン生産する能力を有している。同社は上海か ら北西 $200 \mathrm{~km}$ にある経済開発地区に位置しており, 車両, 鉄道, 船舶のいずれの輸送も可能な立地条件に ある。ダガン工場は揚子江に自社の港も有している。

ダガン工場は高品質の塗工紙を生産しており, その 80\% は国内市場向け, 残りはホンコン, 日本および アメリカに輸出される。原材料の大部分はインドネシ アの APP の親工場から送られる。しかし，短繊維は 南アメリカから輸入される。同社での生産は坪量 80$200 \mathrm{~g} / \mathrm{m}^{2}$ の範囲であり, とりわけ $105-157 \mathrm{~g} / \mathrm{m}^{2}$ の範 囲が主である。

中国の紙消費は成長しており,1999 年には, $30 \mathrm{~kg} /$ 人であったが, 今日では $32 \mathrm{~kg} /$ 人である。上海のよ うないくつかの成長率の高い地域では, この数值は $100 \mathrm{~kg} /$ 人である。中国において非塗工の印刷および 筆記用紙の競争は過酷である。他方では，塗工紙の需 要は国内向け供給よりも高くなっている。
中国の印刷会社は品質的理由から輸入塗工紙の購入 に慣れており，同社は，塗工紙の品質の高さによって， 中国市場での強い地位を築いている。

\subsubsection{OMC 2 オフコーターライン}

1999 年, メッツォペーパーはダガン工場に完全な 仕上げライン（OMC 1）を納入した。2001 年 10 月に は，ほとんど同一の仕上げライン（OMC 2, 図 7）を 再度納入し，スタートアップした。 4 ステーションか らなるOptiCoater であり世界最大である。その紙幅 は 9,770 mm であり，設計速度は $2,000 \mathrm{~m} /$ 分である。 このコーターは 4 台の OptiCoat Jet コーティングス テーション (図8), OptiReel Plusリール, プルグル ープ, 高容量エアドライヤ, IR ドライヤ, および全 コーティングプロセスをコントロールするための近代 的オートメーションを装備している。この他, 2 台の OptiReel レリーラー, 2 台のオフマシン OptiLoad マ ルチニップカレンダー, 2 台の JR $1000 \mathrm{E}$ 生産ワイン ダー, 1 台の WinBelt リワインダー, 4 台のペアレン トリールカートとパルパーが含まれる。

機械に加えて，仕上げラインの電化，140トンの仕 上げライン用クレーン, 工場のエンジニアリングと補 機, 例えばタンク, 配管, 液体ガスシステム, 圧縮空 気システムとスチーム・コンデンセートシステムが含 まれる。

3.4.3 OptiCoater の迅速なスタートアップカーブ

ダガン工場 OMC 1 の OptiCoater は世界でも最も 迅速なスタートアップカーブの一つを示した。販売可 能な紙はわずか 2 週間で達成された。OMC 2 はさら に記録を短縮した。スタートアップ時の速度は 1,400 $\mathrm{m} /$ 分であり, 最終製品の品質は 1 週間で達成された。 2002 年 4 月現在で, 最速の運転速度は $1,650 \mathrm{~m} /$ 分で ある。なお, OMC 1 は最速の運転速度として 1,820 $\mathrm{m} /$ 分を記録している。

\subsubsection{OptiCoater の利点}

OptiCoater の特徵は，シリンダードライヤがない ことである。従来の 4 ステーションコーターレイアウ トでは，シリンダードライヤ群はマシンの全長の 30$70 \%$ を占めている。しかし，これらの伝統的なシリ ンダードライヤ群によって達成される乾燥能力は全乾 燥量のわずか $10 \%$ である。

OptiCoater 技術を用いれば，IR 乾燥と結びつけた 近代的高容量エアドライング技術によって乾燥は行わ れる。スペース縮小の要求と結びついたコスト節減は 欠かせない。従来のコンセプトに比べて, OptiCoater は, $30 \%$ の少ないスペースで $30 \%$ 大きな塗工能力を 提供する。 
PowerDry エアドライヤは高い蒸発能力を有するた めコンパクトな乾燥レイアウトが可能である。最新の エアドライヤノズル技術を用いた乾燥空気の再循環に より,70\%のレンジに近いエネルギー効率が達成され， これによりエネルギーコストが低減される。エアドラ イヤシステムの磨耗パーツが少なく, 部品の償却費も 少なくて済む。

\section{5 サンペーパーの板紙マシン}

サンペーパーは 21 年前に設立された。当時, 中国

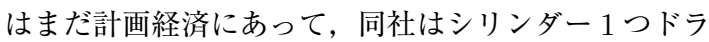
イヤ 1 つの抄紙機しか持っていなかった。しかもマシ ン幅は $1,092 \mathrm{~mm}$ であった。このマシンは最低グレー ドの包装用板紙を製造し，その能力は 1 トン/日であ った。しかし, 1997 年以降，等比級数的な成長を果た し，現在は中国の 5 大製紙工場の 1 つとなっている。 17 の生産ラインを所有しており, 120 以上の品種を含 む 3 つの製品領域を有している。塗工包装用板紙の市 場でのシェアは国内の市場では $25 \%$ に達した。

\subsubsection{PM 17 と PM 18}

塗工板紙は，中国では大量の包装の需要と木材資源 の欠乏のため過去 20 年間で最も成長した紙グレード である。塗工板紙は $80 \%$ が古紙繊維からなっている。 サンペーパーは 2000 年に 350,000 トン/年の能力を有 する 2 つの塗工板紙ラインを 2 段階の工事で設置する 決定をした。

メッツォは，合弁会社である Valmet-Xian ととも に, PM 17 のために MB ハイブリッドフォーマーを 有するフォーミングセクションでの 4 層, プレスセク ションで $2 つ$ LNPと 1 つスムージングプレ ス，84本のシリンダーを有するドライヤセクショ ン，4つのコーティングステーション（トップ面にト リプル塗工，裏面にシングル塗工), $350 \mathrm{t} / \mathrm{d}$ の

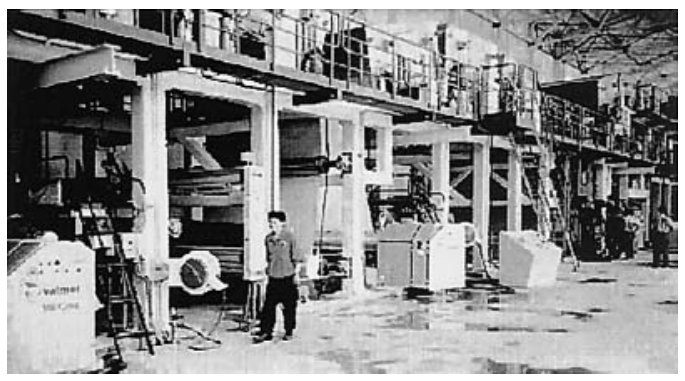

- Board grades : WLC and FBB

- Weight : 150-350 gsm

- Web width : $3.3 \mathrm{~m}$

- Speed : $\quad 400 \mathrm{~m} / \mathrm{min}$

図 9 サンペーパーPM 17
BCTMP 紙料ライン， $200 \mathrm{t} / \mathrm{d}$ の LBKP ラインと $50 \mathrm{t} /$ $\mathrm{d}$ の NBKP リファイニングラインである塗工カード ボードを製造するための 3 つのリファイニングライン を納入した（図 9)。

PM 17 はスタートアップ後 10 ケ月で生産とマーケ ティングはともに成長した。実際の運転速度は約 $10 \%$ 設計速度を上回り，生産は 160,000 トン以上に達した。 こうして PM 17 の成功の結果として, 第二のプロジ エクトであるPM 18 の導入が決まった。PM 18 は 2003 年 10 月にスタートアップの予定である。これは 5 つのコーティングステーションを有し，表面はトリ プル塗工, 裏面はダブル塗工を行う。PM 18 にはデ イルーションヘッドボックス, ソフトカレンダー, 八 ードカレンダーおよびブローク処理システムが含まれ る。塗工カードボードに加えて，アート紙も生産する。

\section{4. まと め}

本稿では近年，日本においても関心の高まっている 中国のマシンの導入状況を紹介した。日本をはじめと して欧米の先進諸国が将来的にも紙・板紙の需要の伸 びが横這いであると予測されるのに対して, 中国は今 後とも大きな需要の伸びが予測されている。

最近の中国へのマシンの導入の傾向として, 中古の マシンの設置も聞くが，やはり世界でも最新式の抄紙 機設備が導入されていることである。メッッォペーパ 一は 1998 年に新世紀用の抄紙機として OptiConceot を発表したが，世界に先駆けて中国のナンピン PM 5 に新聞用紙用抄紙機として導入が決まり，1999 年の 末には稼動してしまった。ハインドル社 Augsburg PM 3 に OptiConcept の LWC 抄紙機が導入され，ス タートアップしたのは 2000 年である。ナンピンの OptiConceptの成功を見て, チチハルにも同型機がいち 早く導入された。以後の導入で興味深い抄紙機は新聞 用紙と LWC を抄き分けられるいわゆるスイングマシ ンである。これは吉林造紙の PM 12 がそれであるが 同社の財政問題から未設置のままなのは残念である。 だが，本年 7 月，岳陽紙業集団のユエヤン PM 8 のス イングマシンがスタートアップしている。また, 山東 チェンミン紙業グループは既に 3 台のメッツォの抄紙 機を有しているが，新たに OptiConcept の LWC 抄紙 機を導入することを決めている。

板紙抄紙機については本文で記した以外にも，今後 いくつかのスタートアップが予定されている。特徽的 なのは世界最大級の塗工板紙 (WLC) マシン（日産 2, 000 トン）が 2004 年にスタートアップを予定して いることである。 